Conserving Biological Diversity in Temperate Forest Ecosystems: Towards Sustainable Management. December 4-9, 1994.

Canberra, Australia. Information: Dr. Tony Norton, International Forest Biodiversity Conference, Centre for Resource and Environmental Studies, Institute of Advanced Studies, The Australian National University, Canberra ACT 0200, Australia. Tel. 61-6-2494143, Fax. 61-6-249-0757.

Stand Establishment and Inter-Rotation Management. March 20-24, 1995.

Second International Conference on Forest Vegetation Management, Rotorua, New Zealand. Information: IFVM \#2, NZ Forest Research Institute, Private Bag 3020 , Rotorua, New Zealand. Tel +64 7 $3475899, \mathrm{Fax}+6473479380$.

\section{IUFRO XX World Congress, August} 6-12, 1995.

Tampere, Finland. The theme of the Congress is "Caring for the Forest: Research in a Changing World". The Congress features opening and closing ceremonies, five keynote addresses, subplenary sessions, inter-divisional sessions, divisional and congress group sessions, and half-day in-congress tours. There will also be 18 post-congress excursions to different parts of Finland and to other Scandinavian countries, the Russian Federation and the Baltic Countries. A special program is being organized for accompanying persons. Information: IUFRO-95 Congress Secretariat, Finnish Forest Research Institute, Unioninkatu 40A, FIN-00170 Helsinki, Finland. Tel. +358-0-857051, Fax. +358-0-625308.

\title{
Publications of Interest
}

\begin{abstract}
MISCELLANEOUS
Research Management in Forestry. 1992. Food and Agriculture Organization of the United Nations. FAO Forestry Paper 102. 120 p.
\end{abstract}

Directory of Forestry Research Organizations. 1993. Food and Agriculture Organization of the United Nations. FAO Forestry Paper 109. 167 p.

Proceedings of the Meeting of Experts on Forestry Research. Rome, 12-14 October 1992. 1992. Food and Agriculture Organization of the United Nations, FAO Forestry Paper 110. 258 p.

\section{US FOREST SERVICE}

Recognizing and Managing Sapstreak Disease of Sugar Maple. 1993. David R. Houston. Northeastern Forest Experiment Station, RP-NE-675.

Test of Four Stand Growth Simulators for the Northeastern United States. 1993. Thomas M. Schuler, David A. Marquis, Richard L. Ernst and Brian T. Simpson. Northeastern Forest Experiment Station, RP-NE-676.

Six-year Beechnut Production in New Hampshire. 1993. William B. Leak and Raymond E. Graber. Northeastern Forest Experiment Station, RP-NE-677.

Survival of Northern Red Oak Acorns After Fall Burning. 1993. L. R. Auchmoody and Clay H. Smith. Northeastern Forest Experiment Station, RP-NE-678.

\section{West Fraser mills Ltd}

\author{
A CIF/IFC Corporate Sustaining Member
}

Protecting Red Oak Seedlings with Tree Shelters in Northwestern Pennsylvania. 1993. Russell S. Walters. Northeastern Forest Experiment Station, RP-NE-679.

Methods to Estimate Total Forest Biomass for Extensive Forest Surveys: Applications in the Northeastern US. 1993. Eric H. Wharton and Douglas M. Griffith. Northeastern Forest Experiment Station, RP-NE-681.

Effects of Forest Disturbance and Soil Depth on Digestible Energy for Moose and White-tailed Deer. 1993. Hewlette S. Crawford, R. A. Lautenschlager, Martin R. Stokes and Timothy L. Stone. Northeastern Forest Experiment Station, RP-NE-682.

Defoliation Potential of Gypsy Moth. 1993. David A. Gansner, David A. Drake, Stanford L. Arner, Rachel R. Hershey and Susan L. King. Northeastern Forest Experiment Station, RN-NE-354.

Proceedings, US Department of Agriculture Interagency Gypsy Moth Research Forum 1993. 1993. Sandra L. C. Fosbroke and Kurt W. Gottschalk., eds. GTR-NE-179.

Bibliography of Forest Service Recreation Research: 1983-1992. 1993. John J. Daigle, compiler. Northeastern Forest Experiment Station, GTR-NE-180.

Effect of Various Proportions of Juvenile Wood on Laminated Veneer Lumber. 1993. David E. Kretschmann et al. Forest Products Laboratory, FPLRP-521.31 p.

Specific Gravity, Moisture Content, and Density Relationship for Wood. 1993. William T. Simpson. Forest Products Laboratory, FPL-GTR-76. 13 p.

Dissolving Pulp Industry: Market Trends. 1993. Irene Durbak. Forest Products Laboratory, FPL-GTR-77. $20 \mathrm{p}$.

Biopulping - A Glimpse of the Future? 1993. T. Kent Kirk et al. Forest Products Laboratory, FPL-RP-523. 74 p.

Using a Growth and Yield Model (PTAEDA2) as a Driver for a Biological 
Process Model (MAESTRO). 1993. V. Clark Baldwin, Jr., H. E. Burkhart, P. M. Dougherty and R. O. Teskey. Southern Forest Experiment Station, Res. Pap. SO-276. 9 p.

Using a Density-management Diagram to Develop Thinning Schedules for Loblolly Pine Plantations. 1993. Thomas J. Dean and V. Clark Baldwin, Jr. Southern Forest Experiment Station, Res. Pap. SO-275. 7 p.

Point Counts of Birds in Bottomland Hardwood Forests of the Mississippi Alluvial Valley: Duration, Minimum Sample Size, and Points Versus Visits. 1993. Winston Paul Smith et al. Southern Forest Experiment Station, Res. Pap. SO-274. $21 \mathrm{p}$.

Hikers and Recreational Stock Users: Predicting and Managing Recreation Conflicts in Three Wildernesses. 1993. Alan E. Watson, Michael J. Niccolucci and Daniel R. Williams. Intermountain Research Station, Res. Pap. INT-468. 35 p.

Elk Management in the Northern Region: Considerations in Forest Plan Updates or Revisions. 1993. Alan G. Christensen, Jack L. Lyon and James W. Unsworth. Intermountain Research Station, Gen. Tech. Rep. INT-303. 10 p.

Fire Growth Maps for the 1988 Greater Yellowstone Area Fires. 1994. Richard C. Rothermel, Roberta A. Chase and Carolyn H. Chase. Intermountain Research Station, Gen. Tech. Rep. INT-304. 64 p.

Some Economic Impacts of the $\mathbf{1 9 8 8}$ Fires in the Yellowstone Area. 1993. Paul E. Polzin, Michael S. Yuan and Ervin G. Schuster. Intermountain Research Station, Res. Note INT-418. 13 p.

Management Impacts on Water Quality of Forests and Rangelands. 1993. Dan Binkley and Thomas C. Brown. Rocky Mountain Forest and Range Experiment Station, Gen. Tech. Rep. RM-239. 114 p.

Managing Pinon-Juniper Ecosystems for Sustainability and Social Needs.
1993. Earl F. Aldon and Douglas W. Shaw. Rocky Mountain Forest and Range Experiment Station, Gen. Tech. Rep. RM-236. 169 p.

\section{FOREST ENGINEERING RESEARCH INSTITUTE OF CANADA}

Work Program 1994. 72 p.

Annual Report 1993. 28 p.

The report includes lists of members of FERIC, the Board of Directors, Advisory Committees, the financial statement, 1993 publications and brief reports on several research projects.

Sawlog Production Within an InWoods Chipping System. 1993. J. Favreau and G. S. Franklin. Technical Note TN-206. 8 p.

Field Notes

The Collins Work-All. Skidding/ Forwarding-25.

Equipping the Farm Tractor for Forest Operations. Skidding-Forwarding-27.

CANADIAN FOREST SERVICE

Forest Pest Conditions in the Maritimes. 1993. L. P. Magasi. Maritimes Region, Inf. Rep. M-X-183E/F.

Three Decades of Dutch Elm Disease in Fredericton, N. B. 1993. L. P. Magasi. K. J. Harrison, D. A. Urquhart and D. M. Murray. Maritimes Region, Inf. Rep. M-X-185E/F.

Breeding Strategies of Important Tree Species in Canada. Proceedings of the Workshop. 1993. Y. S. Park and G. W. Adams. Maritimes Region, Inf. Rep. M-X-186E/F.
Forest Insect and Disease Conditions in Newfoundland and Labrador in 1992. 1993. W. W. Bowers, E. C. Banfield, D. S. O'Brien, D. M. Stone, W. J. Sutton, K. E. Pardy and G. C. Carew. Newfoundland and Labrador Region, Inf. Rep. N-X-289. 40 p.

Boreal Ecosystem Dynamics of ARNEWS Plots: Baseline Studies in the Prairie Provinces. 1994. D. G. Maynard and M. D. Fairbarns. Northwest Forest Region, Inf. Rep. NOR-X-327.

Frost and Other Climate-related Damage of Forest Trees in the Prairie Provinces. 1993. Y. Hiratsuka and H. Zalasky. Northwest Forest Region, Inf. Rep. NOR-X-331.

Forest Insect- and Disease-caused Depletions of Forests of West-central Canada: 1982-87. 1994. J. P. Brandt and P. Amirault. Northwest Forest Region, Inf. Rep. NOR-X-333.

Forest Insect and Disease Conditions in West-central Canada in 1993 and Predictions for 1994. 1994. J. P. Brandt. Northwest Forest Region, Inf. Rep. NOR-X-335.

Forest Inventory Mapping Procedures Across Canada. 1993. M. D. Gillis and D. G. Leckie. Petawawa National Forestry Institute, Inf. Rep. PI-X-114.

Predicting the Daily Occurrence of Lightning-caused Forest Fires. 1993. P. Kourtz and B. Todd. Petawawa National Forestry Institute, Inf. Rep. $\mathrm{PI}-\mathrm{X}-112 \mathrm{E} / \mathrm{F}$.

A Laboratory Guide to Somatic Embryogenesis in Spruce and Larch. 
1993. M. A. Lelu, K. K. Klimaszewska, C. Jones, P. von Aderkas and P. J. Charest. Petawawa National Forestry Institute, Inf. Rep. PI-X-111.

Forest Insect and Disease Survey Strategic Plan 1993-1998. 1994. J. Peter Hall. Science and Sustainable Development. 8 p. Bilingual format.

Forest Depletions Caused by Insects and Diseases in Canada - 1982-1987. Compiled by J. Peter Hall and Ben Moody. Forest Insect and Disease Survey, Information Report ST-X-8. 14 p. Bilingual format.

Impacts of Biomass Harvesting on Soil Disturbance and Surface Soil Erosion at Seller Creek in Interior British Columbia. P. R. Commandeur and M. E. Walmsley. Pacific Forestry Centre. Information Report BC-X-342.

Dynamic Programming: A Tool for Financial Analysis of Stand Management Regimes. William A. White. Pacific Forestry Centre. Information Report BC-X-342.

Dynamic Programming: A Tool for Financial Analysis of Stand Management Regimes. William A. White. Pacific Forestry Centre. Information Report BC-X-343.

Forestry Canada Modelling Working Group: Proceedings of the Seventh Annual Meeting and Workshop, Pacific Forestry Centre, Victoria, BC, February 1993. Compiled by G. M. Bonnor.

\section{Book Reviews / Revue de livres}

Living With Wildlife - A Strategy for Nova Scotia. Nova Scotia Wildlife Advisory Council, Province of Nova Scotia, Halifax, Nova Scotia, 227 p., 1993. Free. ISBN: 0-88871-264-2.

Living With Wildlife - A Strategy for Nova Scotia will be of interest to most Nova Scotians as well as wildlife professionals throughout Canada. The major goal of the book is "to ensure the restoration and maintenance of Nova Scotia's ecosystems and biodiversity, acknowledging our stewardship responsibilities to make certain all wildlife uses and benefits are sustainable for present and future generations". The Strategy is intended to provide both the direction, and the yardstick, for the conservation of wildlife and the natural systems of which they are a part.

The Wildlife Advisory Council conceived and implemented the development of the Strategy. Wildlife related concerns were identified through invited participant workshops, public plenary sessions, and written submissions in 1992. "It is a plan created in large measure by the public for adoption in whole, or in part, by the government".

The Strategy is laid out in five major parts: People and Wildlife; The Land and Wildlife; Research, Management, and Education, Wildlife and the Larger Issues: and Pathways. These sections

\section{Davis \& Company}

BARRISTERS AND SOLICITORS

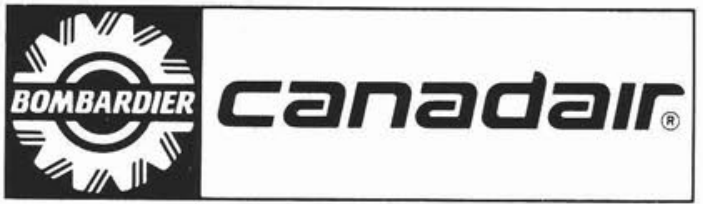

CIF/IFC Corporate Sustaining Members are then subdivided into topic areas such as public attitudes, enforcement, protected areas, and urban wildlife. Each topic includes the related wildlife concerns, followed by a list of recommended objectives and initiatives. Most comments focused on public wildlife on private lands, and wildlife management issues. The objectives reflect nine recurring concepts including: responsible attitudes towards wildlife, wildlife habitat, and private property; encouraging public decision making; and providing opportunities for all wildlife users.

The Wildlife Strategy will greatly influence wildlife policy and management in Nova Scotia, affecting all landowners and wildlife users.

Julie Towers

Extension Specialist, Wildlife Nova Scotia Department of Natural Resources

Rain Coast Chronicles 14: Fish Hooks and Caulk Boots

Florence Tickner, Harbour Publishing, Madeira Park, BC, 80 p. 1993. \$10.95 ISBN 1-55017-078-3

Fish Hooks and Caulk Boots by Florence Tickner is part of a series of chronicles about the west coast. Ms. Tickner lived on the west coast as a girl in the 1930s and 40s. Her father was a logger and the book talks about life in the early float camps.

The book deals mostly with family life in the float camps on the coast of British Columbia but also provides some insight into past logging practices and methods. Although the writing style is rather disjointed, the stories are very interesting and entertaining. The book is full of amusing anecdotes and funny stories. There are stories on moonshining, and hiding poached game from wardens which often lead to quite humorous situations. But of even more interest is the running and life of the early 20 th century logging operations. So often chronicles of life in early logging camps came from the loggers. This book provides a unique view from the family point of view. 